\title{
よく知られていない数種の水産動物油について
}

\section{外山修 之*・高井英子*}

Notes on Some Lesser Known Aquatic Animal Oils.

Yoshiyuki Toyama and Hideko Takai

サカマタ, セミクジラ,ボラ, マアジ, アイナメ, ラ イギヨの油, カツオ肝油, ヒガンフグ肝油の性状飞つい ては今まで全然知られていないか，あるいは 1,2 の試料 油についての試験結果が発表されていると過ぎないか
ら，これらの油の性状と関する知見を補らため，こ」に 著者の試験結果を報告する。

1. サカマタ油 サカマタ Grampus orca (Linné) は一名シャチという, 試料油は旧帝国油糧統制株式会社 表 -1

\begin{tabular}{|c|c|c|c|c|c|c|c|c|c|c|c|c|}
\hline \multirow[b]{2}{*}{ 油 } & \multirow{2}{*}{ 朴 観 } & \multirow[b]{2}{*}{$d_{4}^{20}$} & \multirow[b]{2}{*}{$n_{\mathrm{D}}^{20}$} & \multirow[b]{2}{*}{ 酸 } & \multirow{2}{*}{$\mid \begin{array}{c}\text { ケン人化 } \\
\text { 価 }\end{array}$} & \multirow{2}{*}{ 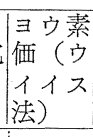 } & \multirow{2}{*}{\begin{tabular}{|c|}
$\mid \begin{array}{l}\text { 不ヶン } \\
\text { 化物 } \\
(\%)\end{array}$ \\
\end{tabular}} & 脂 & & 肪 & 酸 & \multirow[b]{2}{*}{ そ の 他 } \\
\hline & & & & & & & & \multicolumn{4}{|c|}{ 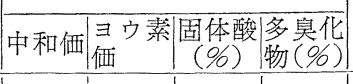 } & \\
\hline カマタ & 橙黄色液状 & 0.9135 & 1.4701 & 1.04 & 186.5 & 112.3 & 7.54 & - & - & - & 21.77 & $\begin{array}{l}\text { ライヘルト・マイスル } \\
\text { 価 } 6.72\end{array}$ \\
\hline ミラジラ & 淡黄色液状 & 0.9196 & 1.4760 & 2.64 & 186.6 & 132.2 & 0.46 & - & - & - & 30.007 & 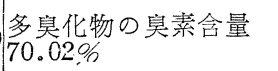 \\
\hline ボラ, 体 & $\begin{array}{l}\text { 橙黄色, 固 } \\
\text { 㤓脂析出 }\end{array}$ & 0.930 & 1.4803 & 1.50 & 197.8 & 159.0 & 0.72 & - & - & 18.30 & $-F$ & 固体酸のヨウ素価 3.1 \\
\hline ナ, 体 & $\begin{array}{l}\text { 橙黄色, 固 } \\
\text { 体脂析出 }\end{array}$ & 0.9298 & 1.4787 & 1.44 & 200.2 & 163.1 & 0.65 & - & - & 20.36 & -1 & 同上，34 \\
\hline イナ，内臟 & 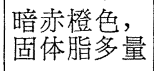 & 0.9361 & 1.4817 & 28.4 & 195.6 & 151.7 & 4.43 & 212.3 & 155.3 & - - & - & 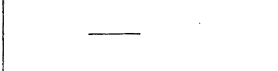 \\
\hline $\begin{array}{l}\text { マアジ（小 } \\
\text { 型）体 }\end{array}$ & \begin{tabular}{|l} 
橙黄色, 固 \\
体脂析出
\end{tabular} & 0.9248 & 1.4818 & 10.6 & 193.6 & 150.4 & 1.48 & 199.2 & 156.3 & - & 58.76 & \\
\hline $\begin{array}{l}\text { マアジ (小 } \\
\text { 型) 内臓 }\end{array}$ & $\begin{array}{l}\text { 暗赤橙色, } \\
\text { 固体脂多量 }\end{array}$ & 0.9327 & 1.4827 & 14.9 & 188.2 & 155.2 & 2.58 & - & - & - & 56.74 & - \\
\hline $\begin{array}{l}\text { マアジ（大 } \\
\text { 型）体（ }\end{array}$ & $\begin{array}{l}\text { 橙黄色, 固 } \\
\text { 体脂少量 }\end{array}$ & $0.916 \stackrel{2}{5}$ & 1.4767 & 3.26 & 192.4 & 136.7 & 1.56 & 198.6 & $\mid 141.9$ & 9 20.57 & 47.45 & 固体酸のヨウ素価 8.7 \\
\hline $\begin{array}{l}\text { マアジ(大 } \\
\text { 型) 内臟 }\end{array}$ & \begin{tabular}{|l|} 
暗赤橙色, \\
固体脂多量
\end{tabular} & $0.9222^{*}$ & 78 & 12.3 & 188.5 & 135.8 & 2.47 & 197.7 & 139.9 & 24.81 & 48.01 & 同上，7.0 \\
\hline 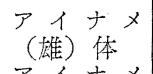 & 橙黄色液状 & - & 1.4801 & 55.0 & 184.7 & 153.9 & 2.19 & 190.0 & 159.8 & 12.81 & $|35.70|$ & 同上, 8.9 \\
\hline 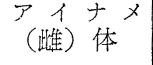 & 橙黄色液状 & - & 1.4807 & 22.5 & 185.2 & 157.1 & 1.02 & 192.1 & 164.4 & 13.59 & 32.83 & 同上, 8.9 \\
\hline $\begin{array}{l}\text { ライギ.ヨ, } \\
\text { 体 }\end{array}$ & $\begin{array}{l}\text { 暗赤橙色, } \\
\text { 固体脂析出 }\end{array}$ & 0.9344 & 1.4776 & 19.5 & 173.3 & 116.7 & 9.95 & 201.5 & 119.2 & 23.80 & 24.49 & 同上, 9.7 \\
\hline $\begin{array}{l}\text { ライギョ, } \\
\text { 内臓 }\end{array}$ & \begin{tabular}{|l|} 
暗赤橙色, \\
固体脂析出
\end{tabular} & 0.9239 & 1.4747 & 2.01 & 189.1 & 124.2 & 4.01 & - & - & 21.40 & 27.19 & 同上，3.7 \\
\hline $\begin{array}{c}\text { カツオ肝臟 } \\
\mathrm{A}\end{array}$ & \begin{tabular}{|l} 
暗赤橙色, \\
固体脂多量
\end{tabular} & 0.9590 & 1.4954 & 75.8 & 166.0 & 219.3 & 13.76 & 186.8 & 237.8 & | - & 82.73 & $\begin{array}{l}\mathrm{E}=35.3 \\
\text { ステリン26.87\% }\end{array}$ \\
\hline $\begin{array}{c}\text { カツオ肝臟 } \\
\text { B }\end{array}$ & $\begin{array}{l}\text { 暗赤登色, } \\
\text { 固体脂多量 }\end{array}$ & 0.9617 & 1.4968 & 82.3 & 161.7 & 223.7 & 16.11 & 187.1 & 244.2 & 2 & 91.56 & $\begin{array}{l}\mathrm{E}=38.5 \\
\text { ステリン } 30.28 \%\end{array}$ \\
\hline $\begin{array}{c}\text { カツオ肝臟 } \\
\text { C }\end{array}$ & 橙黄色 & 0.9200 & 1.5035 & 2.14 & 132.6 & 239.4 & 28.64 & 188.0 & 241.0 & - & 87.25 & $\mathrm{E}=84.7$ \\
\hline $\begin{array}{l}\text { ヒガンフグ } \\
\text { 肝臓 }\end{array}$ & $\begin{array}{l}\text { 淡黄色, 固 } \\
\text { 体脂析出 }\end{array}$ & 0.9243 & 1.4786 & 6.00 & 182.4 & 157.2 & 2.37 & - & - & - & 49.70 & $\mathrm{E}=0.202$ \\
\hline $\begin{array}{l}\text { ヒガンフグ } \\
\text { 肝臟 }\end{array}$ & $\begin{array}{l}\text { 淡黄色, 固 } \\
\text { 体脂析出 }\end{array}$ & 0.925 & 1.4796 & 2.94 & 180.3 & 171.9 & 2.48 & - & - & - & 56.92 & $\begin{array}{l}\mathrm{E}=0.219 \text {,多臭化物の } \\
\text { 臭素含量70.47\%, ステ } \\
\text { リン } 28.66 \%\end{array}$ \\
\hline
\end{tabular}

（備考）外観は常温飞抢ける外観，固体酸は鉛塩エタノール法による。多臭化物はエーテル不溶性臭化物， 肝油の $\mathrm{E}$ 江 $\mathrm{E}_{1 \mathrm{~cm}}^{1 \%} 328 \mathrm{~m} \mu$, ステリンは不ケン化物中の含量。*は $d_{4}^{25}$

* 名古屋大学工学部总用化学教室 (名古屋市千種区不老町) Department of Applied Chemistry, Faculty of Engineering, Nagoya University 
から寄贈を受けたるので，日本海で補獲されたサカマタ から採取されたるのであるという。Bull 和上びSörvig' によるとサカマタ油はケン化価挍よびライヘルト・マイ スル価が高く，殊に上アゴ (顎) 油はケン化価 257.8 , ライヘルト・マイスル価 43.7 でイルカのアゴ油または 頭油似似ている。著者の試料油（表一1）はケン化価が さほど高くないが，その揮発性酸怙よび不ケン化物につ いてつぎの実験を行い，試料油はイルカ科海獣油飞通有 のイソバレリアン酸とセチルアルコール，オレイルアル コールを含むとをを知つた。

試料油 300 g を酒精カリ液でケン化し，つぎにエタ ノールを留去してから希䟽酸を加光て石ケンを分解し, 全液を水蒸気蒸留江附し, 留出液を力性ソーダで中和し て蒸発乾涸し，残留物を硫酸々性にして多量のエーテル で抽出し，エーテル抽出液を飽和食塩水で洗いエーテル を留去してイソバレリアン酸のような臭気を有する液状 酸約 $3 \mathrm{~g}$ を得た。これをメチルエステルとなして蒸留 し、イソバレリアン酸メチルとして沸点 $115 \sim 116^{\circ} \mathrm{C}$ の 部分を捕集した。 $d_{4}^{20} 0.8785 ， n_{\mathrm{D}}^{20} 1.3918$ 。

試料油の不ケン化物 3 倍量のアセトンと溶かし, 溶 液党 $-10^{\circ} \mathrm{C}$ 附近飞冷却乙て析出物分分けた。析出物は 融点 $49.5 \sim 50^{\circ} \mathrm{C}$ で，これをさらにアセトンから分別結 晶したものは融点がそれぞれ $49.5 \sim 51^{\circ} \mathrm{C}, 51 \sim 51.5^{\circ} \mathrm{C}$, 50 50.5ㄷ で主にセチルアルコールと認められた。ま た最初の固体析出物を除いた液体部のアセチル化物はケ ン化価 179.2，ヨウ素価 87.4 で主にオレイルアセデー ト(計算值，ケン化価 180,7，ヨウ素価 81,7) から成 るものと思われた。

2. 七ミクジラ油 試料油は日本水産株式会社旧小笠 原事業場から入手したセミクジラ Balaena glacialis sieboldii Gray の脂肉（体長 $12 \mathrm{~m}$, 牡クジラの脂肉の 一部) から煎取法で採取してものである。

3。ボラ油 ボラ Mugil cephalus L。はとの稚魚を イナと称する。ボラ内臓のエーテル抽出油汇ついては最 近土屋氏等2) の研究が発表された。著者は昭和 27 年秋 飞購入した紀伊産のボラ（1尾の平均重量 $708 \mathrm{~g}$ ) 䊉よ び愛知県知多沿岸産のイナ（1 尾の平均重量 $218 \mathrm{~g}$ ) の 内臓を除いた魚体を水と共竟て上方分離したクリ一 ム状の油層を採つて，乙れを数回水洗してから最後にエ 一テルに溶かし，エーテル溶夜を脱水しエーテルを留去 して油を収得した。内臟は一旦 $60 \sim 80^{\circ} \mathrm{C}$ 飞加熱してか らエーテルで抽出し，エーテル抽出物をアセトンで処理 してアセトン不溶のフォスファチドを除き，アセトン可 溶の油を収得した。油の収量は僅少でボラ体油 $1.2 \%$, イナ体油 $2.7 \%$, イナ内臓油 $3.3 \%$ であつた（実験担 当, 鈴木照二)。

4. マアジ油 マアジ Trachurus japonicus (Temminck \& Schlegel) はアジの種類として最も普通のもの
である。マアジ内臓のエーテル抽出油沉ついては最近土 屋氏等2)の研究が発表された。著者は炤和 27 年秋汇購 入した愛知県近海産のマアジを小型 (1 尾の平均重量 $34 \mathrm{~g}$ ) そ大型（1尾の平均重量 $222 \mathrm{~g}$ ) 飞分け，それ ぞれ内臓を除いた部分飞水を加えて意て，軽く圧些して 粕を除き惹汁を静置して上方と分れた油層を採り，乙れ をボラ油の場合と同様汇処理して油を収得した。油の収 量はいずれる1\%以下であつた。内臓はボラの場合と同 様炕処理して小型魚のものから $8.2 \%$, 大型魚のものか 5 13.3\% の油を収得した（実験担当，柴田昌交）。

5.アイナメ油 アイナメ Hexagrammos otakii Jordan \& Starks の稚魚はクジメと称する。昭和 27 年秋 飞購入した愛知県知多沿岸産のクジメの内贜を除いた部

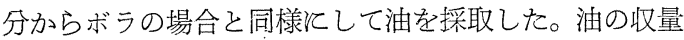
は $1 \%$ 以下でめつた（実験担当，野尼久雄）。

6.ライギヨ油 ライヒー Ophiocephalus tadianus Jordan \& Everman は普通ライギヨと呼ばれる。昭和 27 年秋, 愛知県下の河川産したライギョの魚体 (内

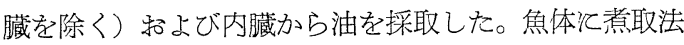
を試みたが油層が分れなかつたから，魚体る内臟と同様 とエーテルで抽出し，エーテル抽出物からアセトン不溶 部を除いて油を収得した（実験担当，山本登）。

7. カツオ肝油 神奈川県沖で漁獲のカツオ Katsu-

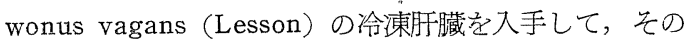
一部党一旦煮沸してからエーテルで抽出し試料油 $A, B$ を収得した。A，B はアセトン処理を行わなかつたから フオスフアチド成分学比較的多量キヨウ雑する招气れが ある。せた試料油Cは上記肝臓の一部门力性ソーダ液を 加光て加熱し， 1 晚静置して上方飞分れた油層を採り，こ れをエーテル溶液となして水洗し，エーテルを留去して 得たものである。油の収量は A7.4\%，B8.6\%，C2.6 \%であつた。最近発表された土屋氏等 ${ }^{21}$ の研究䏓よと カツオ肝油のヨウ素価は 222.3 224.0 であるが，台湾 産カツオ肝油 ${ }^{3)}$ とついてはヨウ素価 114.09〜132.56の 記録がある。著者の肝油試料はヨウ素価が極めて高いこ そが特徵であつて, この点は台湾産カツ才肝油について 発表された記録と著しく相違する。

8.ヒガンフグ肝油 ヒガンフグ Spheroides parda lis (Temminck \& Schlegel) は通俗㶰ヤフグと呼 ばれるととがある。試料油は下関産のヒガンフグの肝蔵 から煎取法で採取したものである。

以上の試料油の性状を一括して表一1 亿示す。

$$
\text { 交献 }
$$

1) Halden-Grün, Analyse der Fette und Wachse, II, 431

2）土屋知太郎，金子良平，遠藤拓治，工化，56，350 (1953)

3）加福均三，池田 鉄作，加藤亮三，日化，54，325 (1933) 